\title{
PENGARUH CORPORATE GOVERNENCE TERHADAP VOLUNTARY DISCLOSURE \\ (Study kasus Pada Perusahaan Manufaktur di Bursa Efek Indonesia pada tahun 2015-2017)
}

\author{
Dianing Ratna Wijayani ${ }^{1}$,Nita Andriyani Budiman², Sri Mulyani ${ }^{3}$ \\ Universitas Muria Kudus \\ ratna.wijayani@umk.ac.id ${ }^{1}$; nita.andriyani@umk.ac.id ${ }^{2}$; s.mulyani@umk.ac.id ${ }^{3}$
}

Diterima: Agustus 2019, Disetujui: September 2019, Dipublikasikan: Oktober 2019

\begin{abstract}
Voluntary disclosure is disclosure that is not requested by regulations. Management is free to choose to provide accounting information and other information that is relevant and supports taking user decisions contained in disclosure of the company's annual report disclosure. This voluntary disclosure is expected to provide complete and transparent information by users of financial statements. The purpose of this study was to study and analyze ownership of institutional ownership, managerial ownership, foreign ownership, board of commissioners, audit board and company size for voluntary disclosure in manufacturing companies on the IDX in 2015-2018.

The population of this study is a manufacturing company on the IDX in 20152018, samples taken using purposive sampling method obtained a sample of 96 companies. The type of data used is secondary data using the data collection method applied. The analytical method in this study is multiple regression analysis.

The results of this study indicate that institutional ownership, board size and company size support voluntary disclosure. Managerial ownership, foreign ownership and ownership audit of voluntary disclosures
\end{abstract}

Keywords: Corporate Governance, Voluntary Disclosure Services

\begin{abstract}
Abstrak
Voluntary disclosure adalah pengungkapan yang tidak diwajibkan oleh peraturan. Manajemen bebas memilih untuk memberikan informasi akuntansi dan informasi lainnya yang dianggap relevan dan mendukung pengambilan keputusan pemakai yang tertuang dalam pengungkapan sukerela laporan tahunan perusahaan. Pengungkapan sukarela tersebut diharapkan dapat memberikan informasi yang lengkap dan transparan oleh pemakai laporan keuangan. Tujuan dari penelitian ini adalah untuk menguji dan menganalisis pengaruh kepemilikan institusional, kepemilikan manajerial, kepemilikan asing, dewan komisaris, komite audit dan ukuran perusahaan terhadap voluntary disclosure pada perusahaan manufaktur di BEI tahun 2015-2018.

Populasi penelitian ini adalah populasi adalah perusahaan manufaktur di BEI tahun 2015-2018, sampel diambil dengan menggunakan metode purposive sampling diperoleh sampel sebanyak 96 perusahaan. Jenis data yang dipergunakan adalah data
\end{abstract}


sekunder dengan menggunakan metode pengumpulan data dokumentasi. Metode analisis pada penelitian ini adalah analisis regresi berganda.

Hasil penelitian ini menunjukkan bahwa kepemilikan institusional, ukuran dewan komisaris dan ukuran perusahaan berpengaruh terhadap voluntary disclosure. Kepemilikan manajerial, kepemilikan asing dan komite audit berpengaruh terhadap voluntary disclosure

Kata Kunci: Corporate Governance, Voluntary Disclosur Service

\section{Pendahuluan}

Seiring dengan pesatnya pertumbuhan dari sektor berbagai usaha sebagai akibat dari globalisasi bahwa perusahaan akan semakin menyadari bahwa untuk kelangsungan hidup dari perusahan juga akan tergantung pada hubungan antara perusahaan dengan masyarakat serta lingkunganya dimana tempat perusahaan itu beroperasi. Hal ini akan sejalan dengan teori legitimasi yaitu perusahaan akan memiliki kontrak dengan masyarakat serta lingkunganya untuk melaksanakan kegiatan-kegiatan perusahaan berdasarkan dari nilai-nilai justice, serta bagaimana cara perusahaan untuk menanggapi atau merespon dari berbagai kelompok kepentingan untuk melegalkan tindakan dari perusahaan. Dan seandainya terjadi ketidakselarasan antara sistem nilai perusahaan serta sistem nilai dari masyarakat, jadi perusahaan dalam kehilangan hak legalnya, yang selanjutnya akan mengancam kelangsungan hidup dari suatu perusahaan (Rawi dan Muchlish, 2010).

Bentuk tekanan globalisasi tersebut dapat berupa tekanan dari pihak-pihak ketiga sebagai partner perusahaan serta pemerintah dan masyarakat. Tekanan pemerintah ditunjukkan dengan adanya Surat dari Keputusan Badan Pengawas Pasar Modal (BAPEPAM) nomer Kep-38/PM/1996 tentang pengungkapan wajib dan pengungkapan sukarela. Peraturan tersebut didukung oleh Ikatan Akuntansi Indonesia (IAI) bahwa dalam Pernyataan Standar Akuntansi Keuangan (PSAK) no.1 (revisi 2015) paragraf sembilan menyarankan yaitu untuk mengungkapkan dari tanggung jawab akan masalah sosial, bahwa perusahaan dapat pula menyajikan laporan-laporan tambahan seperti laporan mengenai lingkungan hidup dan laporan nilai tambah (value added statement), khususnya untuk industri karena faktor lingkungan hidup memegang peran penting dan bagi perusahaan industri yang menganggap pegawai sebagai kelompok dari penguna laporan yang memegang peran penting. 
Voluntary Disclosure adalah suatu pengungkapan yang tidak diwajibkan oleh peraturan. Manajemen akan bebas memilih untuk memberikan suatu informasi akuntansi dan informasi-informasi lain yang dianggap relevan serta mendukung dalam pengambilan suatu keputusan bagi pemakai yang tertuang dalam pengungkapan sukerela laporan tahunan perusahaan. Pengungkapan sukarela tersebut diharapkan dapat memberikan informasi yang lengkap dan transparan oleh pemakai laporan keuangan (Nurkhayati dan Probohudono, 2013). Pentingnya Voluntary Disclosure telah membuat dari banyak peneliti melakukan penelitian serta diskusi mengenai praktik dan faktor yang mempengaruhi pengungkapan sukarela.

Penelitian ini adalah replikasi dari penelitian Nurkhayati dan Probohudono (2013), dan alasan melakukan penelitian ulang adalah hasil penelitian ini belum kuat dalam membuktikan pengaruh ukuran dewan komisaris, kepemilikan menejerial, kepemilkan asing, kepemilikan institusional terhadap voluntary disclosure, sebab hasil penelitian pada variabel bebasnya hanya dapat menjelaskan sebesar $37 \%$ dilihat dari adjusted $R$ Square dan belum dapat membuktikan secara signifikan variabel bebas berpengaruh terhadap voluntary disclosure. Periode penelitian adalah tahun 2015-2017 dan sampel dari penelitian ini adalah perusahaan manufaktur, karena saham perusahaan manufaktur lebih banyak diminati oleh investor daripada sektor lainnya sehingga perusahaan manufaktur akan mengungkapan voluntary disclosure yang lebih luas dan diharapkan variabel corporate governence bisa lebih menjelaskan voluntary disclosure.

\section{Landasan Teori, Kerangka Teoritis dan Pengembangan Hipotesis}

Teori keagenan menjelaskan melalui kontrak antara agen dan principal dalam hubungan kontrak keagenan. Agen cenderung berperilaku oportunistik karena agen memiliki informasi lebih banyak tentang perusahaan, sehingga menyebabkan terjadi asimetri informasi antara pihak agen dan principal, untuk mengurangi asimetri informasi maka diperlukan corporate governance yang baik dalam sebuah perusahaan.

Coporate governance adalah merupakan sepaket peraturan yang mengatur kewajiban dan hak-hak dalam hubungan antara Stakeholder, pengelola perusahaan, pemerintah, kreditur, karyawan dan pemegang kepenringan internal serta eksternalnya. Dengan adanya Good Corporate Governance akan mengurangi asimetri informasi pemegang saham pengendali, serta meningkatkan pengungkapan informasi voluntary 
disclosure untuk menyelaraskan kepentingan antara pemegang saham pengendali dengan pemegang saham minoritas. Agen dapat terdorong buat menyajikan informasi Voluntary Disclosure dapat ditinjau dari Corporate governance yang baik. diantaranya yaitu kepemilikan institusional, kepemilikan manajerial, kepemilikan asing, ukuran dewan komisaris dan komite audit serta variabel kontrolnya yaitu ukuran perusahaan, profitabilitas,tipe industri, auditor eksternal dan leverage.

\section{Gambar 1}

\section{Kerangka Teoritis}

Variabel Independen

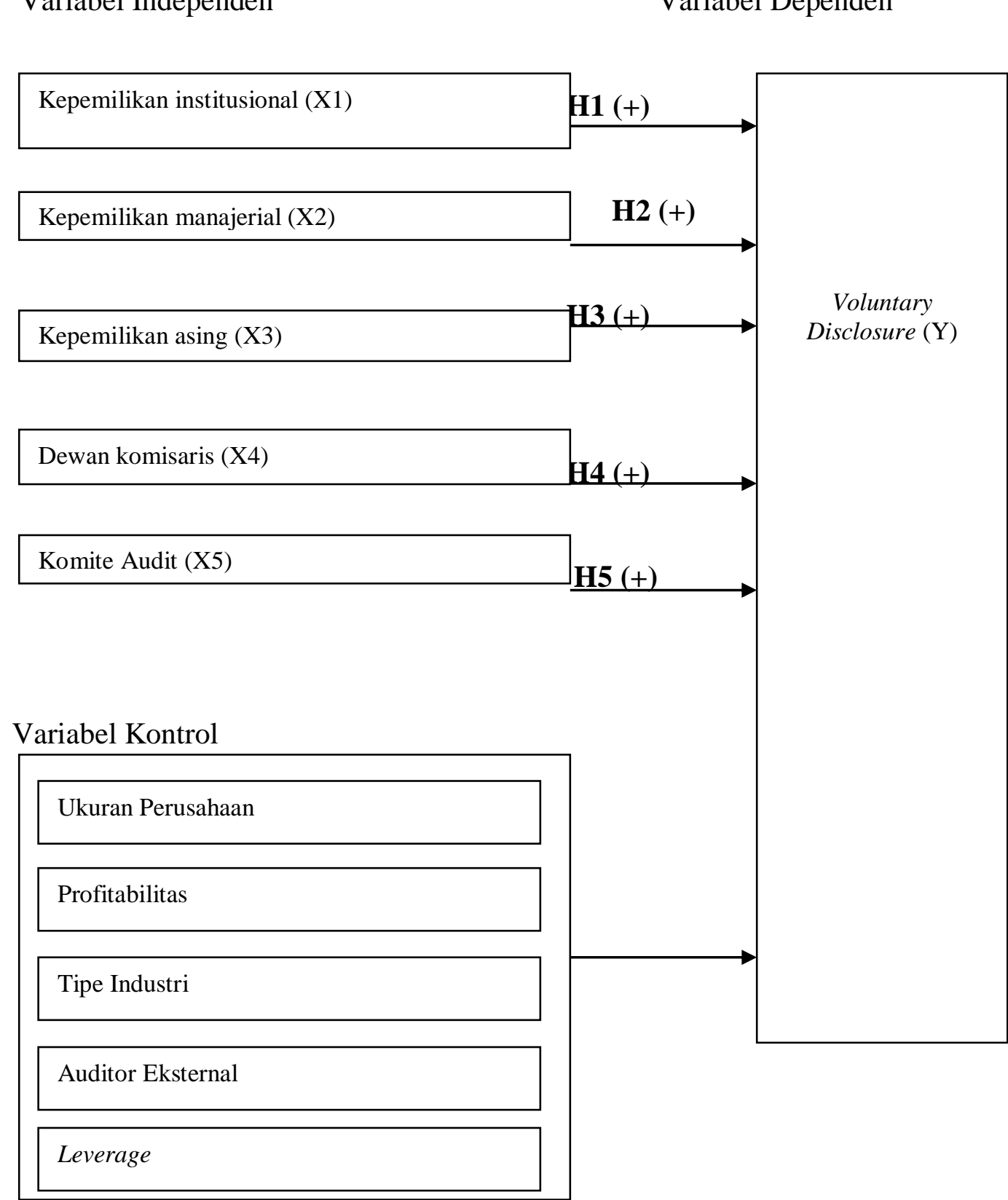

Variabel Dependen 


\section{Pengaruh Kepemilikan Institusional Terhadap Voluntary Disclosure}

Kepemilikan institusional adalah jumlah presentase hak suara yang dimiliki oleh institusi (Beiner et al, 2003). Kepemilikan instituional berpengaruh terhadap pengungkapan voluntary disclosure. Kondisi ini terjadi karena semakin tinggi pihak institusional memiliki saham, maka akan mendorong perusahaan untuk semakin luas dalam pengungkapan voluntary disclosure. Pihak institusional kepentinganya langsung pada perusahaan, dengan pengungkapan sukarela yang lebih luas maka investor institusional akan lebih mempunyai informasi yang lebih luas mengenai peusahaan. Sebagai investor institusi tentunya mempunyai sumber daya yang cukup untuk menganalisis data informasi dari peusahaan, sumber daya yang kuat mendorong perusahaan agar lebih luas dalam mengungkapkan informasi-informasi dalam peusahaan terkait dengan pengungkapan sukarela perusahaan. Keuntungan kepemilikan institusi yang didapatkan dari voluntary disclosure yaitu mendapatkan cukup informasi data perusahaan agar dapat mengambil keputusan untuk kedepanya dalam mempertahankan saham dalam perusahaan .

Hasil penelitian dari Nurkhayati dan Probohudono (2013) serta Mahmud dan Djakman (2008), membuktikan bahwa kepemilikan instituional berpengaruh positif terhadap pengungkapan voluntary disclosure. Berdasarkan uraian tersebut, maka hipotesis yang diajukan adalah sebagai berikut :

$\mathrm{H}_{1}=$ Kepemilikan institusional berpengaruh positif signifikan terhadap voluntary disclosure

\section{Pengaruh Kepemilikan Manajerial Terhadap Voluntary Disclosure}

Kepemilikan asing adalah jumlah presentase hak suara yang dimiliki oleh menejer (Beiner et al, 2003). Manajer akan berusaha untuk memaksimalkan kepentingan dirinya dibandingkan kepentingan perusahaan. Manajer perusahaan memiliki kepentingan mengungkapkan informasi voluntary disclosure untuk mendapatkan citra yang baik dimasyarakat serta produk-produk perusahaan akan lebih diterima pada masyarakat, jika produknya diterima oleh masyarakat dan lingkungan maka laba dari penjualan produk tersebut juga akan semakin meningkat. Sehingga deviden yang diterima oleh manajer disetiap tahunya juga akan semakin meningkat. 
Hasil ini sesuai dengan penelitian Primastuti dan Achmad (2012), yang menyatakan kepemilikan manajerial berpengaruh positif terhadap pengungkapan voluntary disclosure. Berdasarkan uraian tersebut, maka hipotesis yang diajukan adalah sebagai berikut :

$\mathrm{H}_{2}=$ Kepemilikan manajerial berpengaruh positif signifikan terhadap voluntary disclosure

\section{Pengaruh Kepemilikan Asing Terhadap Voluntary Disclosure}

Kepemilikan asing adalah jumlah presentase hak suara yang dimiliki oleh asing (Beiner et al, 2003). Sebagai investor internasional tentu terbiasa dalam mendapatkan transparasi informasi perusahaan dari negara-negara lain dimana ia menanamkan modalnya. Sehingga mendorong perusahaan BUMN Indonesia untuk mengungkapkan laporan pengungkapan sukarela dengan lebih transparan agar mengurangi problem asimetri informasi. Pihak investor internasional juga memiliki resiko yang tinggi dari pada investor lokal, oleh karena itu pihak investor asing menuntut agar perusahaan di Indonesia juga mengungkapkan laporan tambahan terkait laporan pengungkapan sukarela, agar investor asing bisa mengetahui sejauh mana perusahaan dapat mengelola perusahaanya dengan baik. Maka pemilik asing yang besar mengindikasikan tata kelola perusahaan semakin baik, termasuk di dalamnya pelaporan keuangan. Dengan kondisi ini membuat perusahaan yang memiliki kepemilikan asing akan semakin luas dalam mengungkapkan voluntary disclosure.

Hasil penelitian Mahmud dan Djakman (2008), yang menyatakan kepemilikan asing berpengaruh positif signifikan terhadap voluntary disclosure. Berdasarkan uraian tersebut, maka hipotesis yang diajukan adalah sebagai berikut:

$\mathrm{H}_{3}=$ Kepemilikan asing berpengaruh positif signifikan terhadap voulentary disclosure

\section{Pengaruh Ukuran Dewan Komisaris Terhadap Voluntary Disclosure}

Dewan komisaris sebagai puncak dari sistem pengelolaan internal perusahaan, memiliki peranan terhadap aktivitas pengawasan. Komposisi dewan komisaris akan menentukan kebijakan perusahaan termasuk praktek dan pengungkapan voulentary disclosure. Coller dan Gregory (1999) dalam Sembiring (2006) menyatakan bahwa 
semakin besar jumlah anggota dewan komisaris maka akan semakin mudah untuk mengendalikan CEO dan monitoring yang dilakukan akan semakin efektif. Ketentuan yang dimaksud adalah Ketentuan Bapepam dan Peraturan Bursa Efek Indonesia No. 1A tanggal 14 Juli tahun 2004. Ketentuan ini memberikan pengaruh terhadap pengendalian dan pengawasan terhadap manajemen dalam operasi perusahaannya, diantaranya adalah pengungkapan voulentary disclosure.

Hasil penelitian Nurkhayati dan Probohudono (2013) ;Nancy 2010 ;Allegrini dan Greco (2013) ; Yaseen Al Junaedi,et al (2013) membuktikan bahwa ukuran dewan komisaris berpengaruh positif signifikan terhadap voulentary disclosure. Berdasarkan uraian tersebut, maka hipotesis yang diajukan adalah sebagai berikut:

$\mathrm{H}_{4}$ : Ukuran Dewan Komisaris berpengaruh positif signifikan terhadap voulentary disclosure

\section{Pengaruh Komite Audit Terhadap Voluntary Disclosure}

Komite audit adalah komite yang dibentuk oleh dewan komisaris untuk melakukan tugas pemeriksaan dan pengawasan pengelolaan perusahaan. Komite audit juga berfungsi untuk meningkatkan kepercayaan publik terhadap kelayakan dan obyektifitas laporan keuangan serta meningkatkan kepercayaan terhadap adanya kendali internal yang lebih baik. Keberadaan komite audit selaku pengawas pengelolaan keuangan mendorong perusahaan untuk melaporkan laporan keuangan yang lebih baik, sehingga luas pengungkapan voluntary disclosure semakin meningkat (Palestin, 2008). Dengan demikian keberadaan komite audit dapat mendorong perusahaan untuk memperluas pengungkapan voluntary disclosure.

Hasil penelitian Allegrini dan Greco (2011), membuktikan bahwa komite audit berpengaruh positif terhadap voluntary disclosure. Berdasarkan uraian tersebut, maka hipotesis yang diajukan adalah sebagai berikut :

$\mathrm{H}_{5}$ : komite audit berpengaruh positif terhadap voulentary disclosure

\section{Metode Penelitian}

a. Pemilihan Sampel dan Pengumpulan Data

Populasi yang digunakan penelitian ini yaitu perusahaan manufaktur di Bursa Efek Indonesia pada tahun 2015 - 2017. Sampel adalah bagian dari populasi, karakteristik yang hendak diteliti serta diduga dapat mewakili seluruh populasi 
(Sugiyono, 2012). Sampel dalam penelitian ini dari perusahaan manufaktur di Bursa Efek Indonesia pada periode tahun 2015-2017, dan tehnik pengambilan sampel dipilih dengan purpose sampling, yaitu mengambil sampel dengan kriteria-kriteria yang ditetapkan. Kriteria yang di pertimbangjan dalam sampel ini antara lain :

1) Perusahaan manufaktur di Indonesia yang terdapat di BEI tahun 2015 2017.

2) Perusahaan menerbitkan laporan keuangan untuk periode yang berakhir 31 Desember tahun 2015-2017.

3) Perusahaan yang mempunyai data lengkap untuk penelitian

b. Definisi Operasional Variabel

Tabel 2

Definisi Operasional Variabel

\begin{tabular}{|c|c|c|c|c|}
\hline No & Variabel & Definisi Variabel & Indikator & Sumber \\
\hline 1. & $\begin{array}{l}\text { Kepemikan } \\
\text { institusional }\end{array}$ & $\begin{array}{l}\text { Kepemilikan } \\
\text { institusional yaitu } \\
\text { jumlah prosentase } \\
\text { hak suara milik } \\
\text { institusi }\end{array}$ & $\begin{array}{l}\text { Prosentase saham } \\
\text { yang milik institusi } \\
\text { Jumlah saham milik } \\
\text { perusahaan }\end{array}$ & Vu,et al (2011) \\
\hline 2. & $\begin{array}{l}\text { Kepemilikan } \\
\text { manajerial }\end{array}$ & $\begin{array}{l}\text { Kepemilikan } \\
\text { manajerial adalah } \\
\text { jumlah prosentase } \\
\text { hak suara milik } \\
\text { manajerial }\end{array}$ & $\begin{array}{l}\text { Kepemilikan } \\
\text { manajerial penelitian } \\
\text { ini diukur dengan } \\
\text { dummy, yaitu } \\
1 \quad=\quad \text { Memiliki } \\
\text { Kepemilikan } \\
\text { Manajerial } \\
0=\text { tidak Memiliki } \\
\text { Kepemilikan } \\
\text { Manajerial }\end{array}$ & $\begin{array}{l}\text { Eng dan Mak } \\
(2003)\end{array}$ \\
\hline 3. & $\begin{array}{l}\text { Kepemilikan } \\
\text { Asing }\end{array}$ & $\begin{array}{l}\text { Kepemilkan asing } \\
\text { yaitu jumlah } \\
\text { prosentase hak suara } \\
\text { milik asing. }\end{array}$ & $\begin{array}{l}\text { Kepemilkan asing } \\
\text { penelitian ini dikur } \\
\text { dengan dummy, yaitu } \\
1 \quad=\text { Memiliki } \\
\text { Kepemilikan } \\
\text { Asing } \\
0=\text { tidak Memiliki } \\
\text { Kepemilikan } \\
\text { Asing }\end{array}$ & Vu ,et al (2011) \\
\hline 4 & $\begin{array}{l}\text { Ukuran } \\
\text { dewan } \\
\text { Komisaris }\end{array}$ & $\begin{array}{lr}\text { Ukuran } & \text { dewan } \\
\text { komisaris } & \text { yaitu } \\
\text { jumlah } & \text { dewan } \\
\text { komisaris } & \text { dalam } \\
\text { perusahaan } & \\
\end{array}$ & $\begin{array}{l}\text { Jumlah dewan } \\
\text { komisaris }\end{array}$ & Lakhal(2007) \\
\hline
\end{tabular}




\begin{tabular}{|c|c|c|c|c|}
\hline 5. & Komite Audit & $\begin{array}{l}\text { Komite audit yaitu } \\
\text { jumlah dari komite } \\
\text { audit yang dimilik } \\
\text { perusahaan }\end{array}$ & Jumlah Komite Audit & Wilekens (2004) \\
\hline 6. & $\begin{array}{l}\text { Ukuran } \\
\text { Perusahaan }\end{array}$ & $\begin{array}{l}\text { Ukuran perusahaan } \\
\text { didasarkan pada besar } \\
\text { kecilnya perusahaan. } \\
\text { Besar kecilnya } \\
\text { perusahaan } \\
\text { didasarkan pada aset } \\
\text { yang dimiliki oleh } \\
\text { perusahaan }\end{array}$ & LN (Total Asset) & $\begin{array}{l}\text { Hackson dan } \\
\text { Milne (1996) }\end{array}$ \\
\hline 7. & Profitabilitas & $\begin{array}{l}\text { Profitabilitas adalah } \\
\text { kemampuan } \\
\text { perusahaan dalam } \\
\text { memperoleh laba, } \\
\text { bagi pihak yang } \\
\text { berkepentingan } \\
\text { (menejemen,pemegan } \\
\text { g saham serta pihak } \\
\text { kreditur) }\end{array}$ & $\begin{array}{c}\text { Total Laba } \\
\text { Total Asset }\end{array}$ & Riyanto (2010) \\
\hline 8. & Tipe industri & $\begin{array}{l}\text { Tipe industri adalah } \\
\text { pengelompokan jenis } \\
\text { industri dari } \\
\text { perusahaan. Ada } 2 \\
\text { tipe idustri yaitu high } \\
\text { profil dan low profil. } \\
\text { High profile yaitu } \\
\text { perusahaan } \\
\text { otomotif,kontruksi, } \\
\text { pertambangan, } \\
\text { perhutanan, } \\
\text { perikanan, kimia, } \\
\text { barang konsumsi, } \\
\text { minuman serta } \\
\text { makanan, kertas } \\
\text { farmasi dan plastik. } \\
\text { Dan tipe industri low } \\
\text { profil adalah } \\
\text { perusahaan keuangan, } \\
\text { bangunan, suplier } \\
\text { medis,perbankan, } \\
\text { retailer, tekstil dan } \\
\text { produk tekstil, } \\
\text { produk personal serta } \\
\text { rumah tangga }\end{array}$ & $\begin{array}{l}\text { Tipe industri diukur } \\
\text { dengan dummy, yaitu } \\
1=\text { high profile } \\
0=\text { low profile }\end{array}$ & Vu,et al (2011) \\
\hline
\end{tabular}




\begin{tabular}{|c|c|c|c|c|}
\hline 9. & $\begin{array}{l}\text { Auditor } \\
\text { eksternal }\end{array}$ & $\begin{array}{lr}\text { Auditor } & \text { eksternal } \\
\text { adalah auditor } & \text { yang } \\
\text { berasal dari } & \text { luar } \\
\text { perusahaan }\end{array}$ & $\begin{array}{l}\text { Auditor eksternal di } \\
\text { ukur dengan } \\
\text { menggunakan } \\
\text { dummy } \\
1=\text { the big four } \\
0=\text { non the big four }\end{array}$ & Amalia (2008) \\
\hline 10. & Leverage & $\begin{array}{lr}\text { leverage } & \text { adalah } \\
\text { kemampuan } & \\
\text { perusahaan } & \text { untuk } \\
\text { memenuhi } & \text { semua } \\
\text { kewajiban. } & \\
\end{array}$ & $\frac{\text { Hutang }}{\text { Aktiva }}$ & Riyanto(2010) \\
\hline 11. & $\begin{array}{l}\text { Voluntary } \\
\text { Disclosure }\end{array}$ & $\begin{array}{l}\text { Voluntary disclosure } \\
\text { yaitu pengungkapan } \\
\text { yang dilakukan } \\
\text { sukarela oleh suatu } \\
\text { perusahaan yang } \\
\text { tidak diharuskan oleh } \\
\text { peraturan yang } \\
\text { berlaku }\end{array}$ & $\begin{array}{l}\text { Volutary disclosure: } \\
\text { Item diungkapan } \\
\text { perusahaan } \\
33 \\
\text { pengungkapan item }\end{array}$ & Suripto (1999) \\
\hline
\end{tabular}

\section{c. Metode Analisis Data}

Data yang dikumpulkan dalam penelitian ini diolah dan dianalisis dengan menggunakan statistik deskriptif, yang merupakan metode-metode statistik yang digunakan untuk menggambarkan data yang telah dikumpulkan. Statistik deskriptif memberikan gambaran atau deskripsi suatu data yang dilihat dari nilai rata-rata, standar deviasi, varian, maksimum, minimum (Ghozali, 2013).

\section{Hasil dan Pembahasan Hasil Uji Hipotesis}

Tabel 3

Hasil Pengujian Hipotesis

Coefficients ${ }^{\mathrm{a}}$

\begin{tabular}{|c|c|c|c|c|c|c|}
\hline \multirow{2}{*}{\multicolumn{2}{|c|}{ Model }} & \multicolumn{2}{|c|}{$\begin{array}{l}\text { Unstandardized } \\
\text { Coefficients }\end{array}$} & \multirow{2}{*}{$\begin{array}{c}\begin{array}{c}\text { Standardized } \\
\text { Coefficients }\end{array} \\
\text { Beta }\end{array}$} & \multirow[b]{2}{*}{$t$} & \multirow[b]{2}{*}{ Sig. } \\
\hline & & $B$ & Std. Error & & & \\
\hline \multirow[t]{11}{*}{1} & (Constant) & .562 & .068 & & 8.282 & .000 \\
\hline & K. Institusional & .001 & .000 & .278 & 2.099 & .041 \\
\hline & K. Manajerial & -.013 & .010 & -.140 & -1.304 & .198 \\
\hline & K. Asing & -.007 & .011 & -.083 & -.619 & .539 \\
\hline & Ukuran DK & .006 & .003 & .262 & 2.057 & .045 \\
\hline & Komite Audit & .000 & .003 & -.006 & -.047 & .962 \\
\hline & Size & .009 & .004 & .477 & 2.506 & .015 \\
\hline & Profitabilitas & -.021 & .074 & -.048 & -.283 & .778 \\
\hline & Tipe Industri & .024 & .010 & .067 & 2.432 & .037 \\
\hline & Auditor Eksternal & -.012 & .008 & -.193 & -1.577 & .121 \\
\hline & Leverage & -.032 & .023 & -.238 & -1.414 & .163 \\
\hline
\end{tabular}

a. Dependent Variable: Voluntary Disclosure 


\section{Pengaruh Kepemilikan Institusional Pada Voluntary Disclosure}

Kepemilikan Institusional berpengaruh positif signifikan terhadap voluntary disclosure, hasil ini dibuktikan dengan nilai koefisien regresi 0,001 dan nilai signifikasi $0,041<0,05$. Dengan demikian dapat disimpulkan bahwa $\mathrm{H}_{1}$ diterima, sehingga hipotesis yang menyatakan dugaan adanya pengaruh positif antara kepemilikan institusional terhadap voluntary disclosure diterima.

\section{Pengaruh Kepemilikan Manajerial Pada Voluntary Disclosure}

Kepemilikan manajerial berpengaruh negatif tidak signifikan terhadap voluntary disclosure, hasil ini dibuktikan dengan nilai koefisien regresi -0,013 dan nilai signifikasi 0,198>0,05. Dengan demikian dapat disimpulkan bahwa $\mathrm{H}_{2}$ ditolak, sehingga hipotesis yang menyatakan dugaan adanya pengaruh positif antara kepemilikan manajerial terhadapvoluntary disclosure ditolak.

\section{Pengaruh Kepemilikan Asing Pada Voluntary Disclosure}

Kepemilikan asing berpengaruh negatif tidak signifikan terhadap voluntary disclosure, hasil ini dibuktikan dengan nilai koefisien regresi -0,007 dan nilai signifikasi 0,539>0,05. Dengan demikian dapat disimpulkan bahwa $\mathrm{H}_{3}$ ditolak, sehingga hipotesis yang menyatakan dugaan adanya pengaruh positif antara kepemilikan asing terhadap voluntary disclosure ditolak.

\section{Pengaruh Ukuran Dewan Komisaris Pada Voluntary Disclosure}

Ukuran dewan komisaris berpengaruh positif signifikan terhadap voluntary disclosure, hasil ini dibuktikan dengan nilai koefisien regresi 0,006 dan nilai signifikasi $0,045<0,05$. Dengan demikian dapat disimpulkan bahwa $\mathrm{H}_{4}$ diterima, sehingga hipotesis yang menyatakan dugaan adanya pengaruh positif antara ukuran dewan komisaris terhadap voluntary disclosure diterima.

\section{Pengaruh Komite Audit Pada Voluntary Disclosure}

Komite audit berpengaruh negatif tidak signifikan terhadap voluntary disclosure, hasil ini dibuktikan dengan nilai koefisien regresi -0,000 dan nilai signifikasi 0,962> 0,05. Dengan demikian dapat disimpulkan bahwa $\mathrm{H}_{5}$ diterima, sehingga hipotesis yang menyatakan dugaan adanya pengaruh positif antara komite audit terhadap voluntary disclosure ditolak. 


\section{Hasil Uji F}

Nilai signifikasi F sebesar 0,000 < 0,05 .Jadi variabel indepen dalam penellitian ini yaitu kepemilikan institusional, kepemilikan manajerial, kepemilikan asing dan kepemilikan dewan komisaris, komite audit, ukuran perusahaan, profitabilitas, tipe industri, auditor eksternal, leverage secara bersamaan berpengaruh signifikan pada voluntary disclosure Maka dapat diambil kesimpulan bahwa model regresi pada penelitian ini tergolong fit dan dapat digunakan dalam penelitian ini.

\section{Hasil Uji Koefisien Determinasi}

Nilai koefisien determinasi untuk variabel independen (kepemilikan institusional, kepemilikan manajerial, kepemilikan asing, ukuran dewan komisaris, komite audit, ukuran perusahaan, profitabilitas, tipe industri, auditor eksternal, leverage) berpengaruh terhadap variabel dependen (voluntary disclosure) sebesar $41 \%$ sedangkan sisanya dijelaskan faktor lain dalam penelitian ini seperti aktivitas,likuiditas dan lainnya.

\section{Pembahasan}

\section{a. Pengaruh Kepemilikan Institusional Terhadap Voluntary Disclosure}

Kepemilikan institusional berpengaruh positif signifikan terhadap voluntary disclosure. Kondisi ini terjadi karena semakin tinggi pihak institusional memiliki saham, maka akan mendorong perusahaan untuk semakin luas dalam pengungkapan voluntary disclosure. Pihak institusional berkepentingan dalam pengungkapan sukarela yang lebih luas,agar investor institusional mempunyai informasi yang lebih luas mengenai perusahaan. Sebagai investor institusi tentunya mempunyai sumber daya yang cukup untuk menganalisis data informasi dari peusahaan, sumber daya yang kuat mendorong perusahaan agar lebih luas dalam mengungkapkan informasi-informasi dalam perusahaan terkait dengan pengungkapan sukarela perusahaan. Keuntungan kepemilikan institusi yang didapatkan dari voluntary disclosure yaitu mendapatkan cukup informasi data perusahaan agar dapat mengambil keputusan untuk kedepanya dalam mempertahankan saham dalam perusahaan. Hasil penelitian Nurkhayati dan probohudono (2013) serta Mahmud dan Djakman (2008), membuktikan bahwa 
kepemilikan instituional berpengaruh positif terhadap pengungkapan voluntary disclosure

\section{b. Pengaruh Kepemilikan Manajerial Terhadap Voluntary Disclosure}

Kepemilikan manajerial berpengaruh negatif tidak signifikan terhadap voluntary disclosure. Kondisi ini terjadi karena jumlah kepemilikan manajerial dalam penelitian ini cukup kecil sebesar 13 persen, tidak signifikan dengan jumlah saham yang beredar dalam perusahaan, maka manajer tidak mempunyai otoritas dalam menentukan informasi-informasi penting yang disajikan dalam pengungkapan voluntary disclosure, sehingga peranannya dalam pengambilan kebijakan pengungkapan voluntary disclosure kurang terlihat. Hasil ini sesuai dengan penelitian Nancy Yunita (2010) serta Nurkhayati dan Probohudono (2013), yang menyatakan kepemilikan manajerial berpengaruh negatif tidak signifikan terhadap voluntary disclosure.

\section{c. Pengaruh Kepemilikan Asing Terhadap Voluntary Disclosure}

Kepemilikan asing berpengaruh negatif tidak signifikan terhadap voluntary disclosure. Kondisi ini terjadi karena investor asing lebih fokus terhadap deviden yang di dapatkan setiap tahunnya dari pada mengalisis laporan pengungkapan sukarela, sebab kepemilikan asing belum mempunyai sumberdaya yang cukup untuk mengalisis laporan voluntary disclosure, sehingga besar kecilnya kepemilikan asing tidak mempengaruhi pengungkapan voluntary disclosure. Selain itu sampel dalam penelitian ini memiliki kepemilikan asing yang cukup kecil, sehingga dampaknya terhadap voluntary disclosure tidak terbukti. Hasil ini mendukung penelitian Nurkhayati dan Probohudono (2013), yang menyatakan kepemilikan asing berpengaruh negatif tidak signifikan terhadap voluntary disclosure.

\section{d. Pengaruh Ukuran Dewan Komisaris Terhadap Voluntary Disclosure}

Ukuran dewan komisaris berpengaruh positif signifikan terhadap voluntary disclosure. Kondisi ini terjadi karena semakin besar jumlah anggota dewan komisaris, maka akan semakin mudah untuk mengendalikan CEO dan monitoring yang dilakukan akan semakin efektif. Ketentuan ini memberikan pengaruh pengendalian dan pengawasan terhadap manajemen dalam operasi perusahaannya, diantaranya adalah pengungkapan voulentary disclosure. Hasil penelitian ini sesuai dengan penelitian Nurkhayati dan Probohudono (2013) ;Nancy 2010 ;Allegrini dan Greco (2013) ; Yaseen 
Al Junaedi,et al (2013), yang menyatakan ukuran dewan komisaris berpengaruh positif signifikan terhadap voluntary disclosure.

\section{e. Pengaruh Komite Audit Terhadap Voluntary Disclosure}

Komite audit berpengaruh negatif tidak signifikan terhadap voluntary disclosure. Hal ini ditunjukan dengan tingkat singnfikan pengaruh komite audit terhadap voluntary disclosure sebersar 0,962. Ternyata besar kecilnya jumlah komite audit tidak mempengaruhi voluntary disclosure. Karena komite audit yang besar tanpa diimbangi dengan aktivitas pengawasan, frekuensi rapat dan frekuensi jumlah yang hadir dalam rapat tidak akan efektif, sehingga jumlah komite audit kurang berpengaruh dalam kebijakan voluntary disclosure.Hasil ini mendukung penelitian Mujiyono dan Magdalena Nany (2010) serta Yaseen Al Junaedi,et al (2013), yang menyatakan bahwa komite audit berpengaruh negatif tidak signifikan terhadap voluntary disclosure.

\section{Penutup}

\section{Simpulan}

Kepemilikan institusional, ukuran dewan komisaris bepengaruh positf signifikan terhadap pengungkapan voluntary disclosure. Kepemilikan manajerial, kepemilikan asing dan komite audit berpengaruh negatif tidak signifikan terhadap voluntary disclosure.

\section{Keterbatasan}

Penelitian ini menggunakan sampel yang relatif kecil,dikarenakan periode penelitian hanya 3 tahun yaitu 2015-2017, sehingga sangat besar kemungkinan sampel tidak mampu mereprentasikan populasi dengan baik. Sampel yang digunakan dalam penelitian ini hanya terfokus pada perusahaan manufaktur, sehingga kesimpulan yang dihasilkan dari penelitian ini tidak dapat digeneralisasi industri yang lain. Variabel bebas dalam penelitian ini kepemilikan institusional, kepemilikan manajerial, kepemikan asing, jumlah dewaan komisaris dan komite audit hanya dapat menjelaskan variabel dependenya (Voluntary disclosure) sebesar $41 \%$ adalah relatif masih rendah.

\section{Saran}

Sampel yang digunakan hendaknya lebih besar yaitu dengan memperpanjang periode pengamatan agar hasil populasi dari sampel dapat dipresentasikan dengan baik. Sampel yang digunakan sebaiknya tidak hanya perusahaan BUMN saja, misal seluruh 
perusahaan yang terdaftar di Bursa Efek Indonesia agar hasil penelitian mendukung kesimpulan yang lebih akurat. Dalam penelitian ini variabel bebas hanya menjelaskan 41\% dapat dilihat pada nilai Adjusted R Square, maka bagi penelitian selanjutkan perlu ditambahkan variabel bebas misalnya ukuran perusahaan karena perusahaan dengan ukuran yang besar secara umum akan mengungkapkan informasi yang lebih luas.

\section{Daftar Pustaka}

Ainun Naim dan Rahmna Fuad. 2000. Analisis Hubungan Antara Kelengkapan Pengungkapan Laporan Keuangan dengan Struktur Modal dan Tipe Kepemilikan Perusahaan. Jurnal Ekonomi dan Bisnis Indonesia Vol. 15 No. 14.

Al-Janadi,Yaseen et al. 2013 Corporate Governance Mechanisms and Voluntary Disclosure I in Saudi Arabia, Journal of Finance and Accounting. Vol. 4 No. 4.

Allegrini, Marco dan Giulio Greco. 2011. Corporate boards, audit committees and voluntary disclosure: evidence from Italian Listed Companies. Springer Science - Business Media. LLC.

Amalia, Luciana Spica. 2008. Faktor-Faktor Yang Mempengaruhi Pengungkapan Sukarela. Jurnal Akuntansi dan Auditing Indonesia Vol. 12 No.2.

Andi Kartika. 2009. Faktor-Faktor Yang Mempengaruhi Kelengkapan Pengungkapan Laporan Keuangan Pada Perusahaan Manufaktur Yang Terdaftar di Bursa Efek Indonesia. Kajian Akuntansi Vol.1 No.1 ISSN 19794886.

Devina Florenca, Suryanto, L dan Zulaikha, 2004, Pengaruh Karakteristik Perusahaan Terhadap Pengungkapan Sosial Dalam Laporan Tahunan Perusahaan Go Publik di Bursa Efek Jakarta, Jurnal Maksi Vol. 4 Agustus 2004.

Eddy Rismanda Sembiring, 2006, Karakteristik Perusahaan dan Pengungkapan Tanggung Jawab Sosial Study Empiris Pada Perusahaan Yang Tercatat Di Bursa Efek Jakarta. Simposium Nasional Akuntansi VIII, Solo.

Eng, L.L dan Y.T.Mak. 2003. Corporate Governance and Voluntary Disclosure. Journal of Accounting and Public Policy 22 (2003) 325-345.

FCGI, 2000, Peranan Dewan Komisaris dan Komite Audit Dalam Pelaksanaan Corporate Governance (Tata Kelola Perusahaan).Seri Tata Kelola Perusahaan (Corporate Governance), Jilid Kedua Jakarta.

FCGI, 2001, Tata Kelola Perusahaan, Jakarta.

Hackston David dan Markus J.Milne. 1996. Some Determinants of Social and Environmental Disclosures in New Zealand Companies. www.emeraldinsight.com/ journals.htm?articleid=1509110 
Halima Shatila Palestin. 2008. Pengaruh Struktur Kepemilikan, Ukuran Perusahaan dan Corporate governance Terhadap Manajemen Laba, Jurnal Akuntansi dan Binisis Vol. 10.

IAI (Ikatan Akuntan Indonesia). 2015. Standart Akuntansi Keuangan.https://staff.blog.ui.ac.id/martani/pendidikan/slide-psak/.

Imam ghozali, 2005, Aplikasi Multivariate Dengan Program SPSS, Badan Penerbit Universitas Diponegoro,Semarang.

Komite Nasional Kebijakan Governance.2004. Pedoman tentang komisaris independen. http://www.governance-indoneia.or.id/main.htm

Lakhal Faten. 2007. Voluntary Earnings Disclosures and Corporate Governance: Evidence from France. Review of Accounting and Finance.

Machmud Novita dan Djakman D. Chaerul. 2008. Pengaruh Stuktur Kepemilikan Terhadap Luas Pengungkapan Tanggungjawab Sosial Pada Laporan Tahunan Perusahaan : Studi Empiris Pada Perusahaan Publik Yang Tercatat di Bursa Efek Indonesia Tahun 2006. SNA XI Pontianak.

Mujiyono dan Magdalena Nany. 2010. Pengaruh Leverage, Saham Publik, Size dan Komite Audit Terhadap Luas Pengungkapan Sukarela. Jurnal Dinamika akuntansi Vol. 2 No. 2 September 2010.

Nancy Yunita. 2010. Pengaruh Corporate Governance Terhadap Voluntary Disclosure dan Biaya Hutang. Jurnal Ilmiah Mahasiswa Akuntansi Vol. 1 No. 1 Januari 2010.

Nurkhayati Diyan dan Probohudono Agung Nur . 2012. Pengaruh Corporate Governance Terhadap Voluntary Disclosure: Studi Empiris Pada Perusahaan BUMN Di Bursa Efek Indonesia Tahun 2009-2011. SNA XVI Manado.

Nur Indriantoro dan Bambang Supomo, 2008, Metodologi Penelitian Bisnis : Untuk Akuntansi dan menejemen, Cetakan 2, Edisi 1,BPFE, Yogyakarta.

Rawi dan Munawar Muchlish. 2010. Kepemilikan Manajemen, Kepemilikan Institusi, Leverage, dan Corporate Social Responsibility. Simposium Nasional Akuntansi XIII. AKPM_23.

Riyanto Bambang. 2010. Dasar-Dasar Pembelanjaan. BPFE. Yogyakarta

Singarimbun, Masri dan Efendi, Soffyan. 2008. Metodologi Penelitian Survey. LP3ES. Jakarta.

Suripto Bambang. 1999. Pengaruh Karekteristik Perusahaan Terhadap Luas Pengungkapan Sukarela Dalam Laporan Keuangan Tahunan, Thesis S-2, UGM. 
S. Munawir. 2011. Analisis Laporan Keuangan. Liberty. Yogyakarta

Sugiyono. 2012. Metodelogi Penelitian Bisnis. BPFE. Yogyakarta.

Ukago Kristianus, 2005. Faktor-faktor yang berpengaruh terhadp ketetapan waktu pelaporan keuangan bukti empiris di bursa efek Jakarta. Tesis Undip dipublikasikan.

Vu Anh Kelly. Greg Tower dan Glennda Scully. 2011. Corporate Communication for Vietnamese for Vietnamese Listed Firms. www.emeraldinsight.com/13217348.htm

Wilekens. M. H. Bauwhede dan A Gaeremynck. 2004. Voluntary Audit Committe Formation and Practices Among Belgian Listed Companies. International Juournal of Auditing. 8. ISS.3. 207-222. 
Majalah Ilmiah Solusi

Vol. 17, No. 4 Oktober 2019

ISSN : 1412-5331

Halaman ini sengaja dikosongkan 